\title{
Increased Ability Reading The Beginning Using Image Media in Grade I SDN 03 Kebagusan
}

\section{Hindayati}

SD Negeri 03 Kebagusan

hindayatilova@gmail.com

Article History

accepted 14/11/2020

approved 21/11/2020

published 26/11/2020

\begin{abstract}
The purpose of the study was to improve the learning outcomes of students in the Indonesian Language Muple Class I Elementary School using picture media. The research conducted was a Classroom Action Research (CAR) in two cycles, with each cycle planning, implementing, observing and reflecting. Each meeting was carried out in a pretest and posttest of $68.42 \%$, in cycle II students who completed after carrying out a post test of $78.90 \%$, these results indicate that the media image can improve student learning outcomes, especially Class I Mupel in SDN 03 Goodness.
\end{abstract}

Keywords: Learning outcomes, image media

\section{Abstrak}

Tujuan dari penelitian adalah untuk meningkatkan hasil belajar peserta didik pada Mupel Bahasa Indonesia di Sekolah Dasar kelas I dengan media gambar. Penelitian yang dilakukan adalah Penelitian Tindakan Kelas (PTK) sebanyak dua siklus, dengan setiap siklusnya perencanaan, pelaksanaan, observasi dan refleksi. Setiap pertemuan dilakukan pretest dan postest sebesar $68,42 \%$, pada siklus II peserta didik yang tuntas setelah melaksanakan post test sebesar 78,90\%, hasil ini menunjukkan bahwa media gambar dapat meningkatkan hasil belajar peserta didik khususnya Mupel Bahasa Indonesia kelas I di SDN 03 Kebagusan.

Kata kunci: Hasil belajar, media gambar

Social, Humanities, and Education Studies (SHEs): Conference Series

p-ISSN 2620-9284 https://jurnal.uns.ac.id/shes 


\section{PENDAHULUAN}

Pembelajaran bahasa Indonesia bertujuan agar peserta didik memiliki kemampuan berkomunikasi dalam bahasa Indonesia dengan baik dan benar, baik secara lisan maupun tulis, serta menumbuhkan apresiasi terhadap hasil karya sastra Indonesia. Dalm Standar isi, ruang lingkup pembelajaran Bahasa Indonesia terdiri atas menyimak, membaca, berbicara, dan menulis. Dalam hal ini kemampuan membaca perlu dapat perhatian secara khusus dari guru. Adapun salah satu kemampuan membaca yang harus dikuasai peserta didik di kelas 1 sekolah dasar adalah kemapuan membaca permulaan. Peserta didik kelas satu sekolah dasar diharap mampu membaca permulaan dengan lafal dan intonasi yang tepat.

Namun berdasarkan pengalaman mengajar dan hasil observasi pada peserta didik kelas I SD Negeri 03 Kebagusan Kecamatan Ampelgading Kabupaten Pemalang masih banyak peserta didik yang mengalami masalah dalam membaca pemulaan pada mata pelajaran bahasa Indonesia. Peserta didik dalam membaca masih banyak yang belum memperhatikan jeda dan lafal yang tepat, sehingga intonasi dalam membaca lancarpun masih belum tepat. Tentu saja hal ini sangat memprihatinkan mengingat peranan membaca sangat penting dalam proses belajar mengajar. dari 19 peserta didik, hanya 5 anak atau 26,32\% saja yang mempunyai kemampuan yang baik dalam membaca.

Untuk meningkatkan kemampuan membaca siswa kelas I SD N 03 Kebagusan, peneliti akan menggunakan media gambar. Gambar merupakan media yang dapat dipergunakan untuk berbagai permainan yang dapat membuat anank didik senang melakukannya. Gambar juga merupakan sarana atau media untuk merangsang motivasi siswa dalam meningkatkan kemampuan membaca permulaan. Karena dengan gambar-gambar yang beragam siswa akan termotivasi untuk membaca.

Berdasarkan kenyataan yang terjadi di atas, peneliti merasa perlu mengatasi kurangnya kemampuan membaca permulaan peserta didik kelas 1 SD Negeri 03 Kebagusan Kecamatan Ampelgading agar ada peningkatan dalam kemampuan membaca lancar minimal $80 \%$ dari jumlah peserta didik yang ada.

Dalam kamus Besar Bahasa Indonesia tertulis bahwa membaca adalah melihat serta memahami apa yang tertulis dengan melisankan atau dalam hati. Membaca dapat pula diartikan sebagai metode yang kita pergunakan untuk berkomunikasi dengan diri kita sendiri maupun dengan orang lain Tarigan (1986:8). Sedang menurut Layla dalam kamus lengkapnya menyebutkan bahwa baca atau membaca adalah mengeja atau melafalkan apa yang tertulis, melihat serta memahami isi dari apa yang tertulis.

Menurut Solchan T.W., dkk "Kemampuan membaca permulaan lebih diorientasikan pada kemampuan membaca tingkat dasar, yakni kemampuan melek huruf. Maksudnya anak-anak dapat mengubah dan melafalkan lambang-lambang tertulis menjadi bunyi-bunyi bermakna". Dalam tahap ini anak-anak dapat melafalkan lambanglambang bunyi tanpa diikuti pemahaman terhadap lambang-lambang bunyi tersebut.

Dari beberapa pengertian di atas dapat disimpulkan bahwa, membaca permulaan adalah kemampuan membaca dasar yang harus dikuasai oleh siswa sejak dini. Membaca permulaan merupakan tahapan proses membaca bagi siswa sekolah dasar kelas awal. Siswa belajar untuk memperoleh kemampuan dan menguasai teknikteknik membaca dan menangkap isi bacaan dengan baik. Kemampuan membaca permulaan berkaitan langsung dengan seluruh proses pembelajaran di sekolah. 
Menurut H.G.Tarigan (2008: 7) mendefinisikan pengertian membaca adalah sebagai suatu proses yang dilakukan serta dipergunakan oleh pembaca untuk memperoleh pesan yang hendak disampaikan oleh penulis melalui media kata-kata atau bahasa tulis. Membaca mencakup: (1) membaca merupakan suatu proses, (2) membaca adalah strategis, dan (3) membaca merupakan interaktif. Membaca merupakan suatu proses dimaksudkan informasi dari teks dan pengetahuan yang dimiliki oleh pembaca mempunyai peranan yang utama dalam membentuk makna.

Menurut Kamus Besar Bahasa Indonesia (1999: 623), "kemampuan" berarti kesanggupan atau kecakapan. "Membaca" berarti melihat serta memahami isi dari apa yang tertulis, atau mengeja dan melafalkan apa yang tertulis (KBBI,1999: 72). Membaca permulaan merupakan tahap awal dalam belajar membaca yang difokuskan kepada mengenal simbol-simbol atau tanda-tanda yang berkaitan dengan huruf-huruf sehingga menjadi pondasi agar anak dapat melanjutkan ketahap membaca permulaan (Darwadi 2002).

Menurut Yusuf Hadi Miarso seperti dikutip Dwi Rianarwati (2006: 8), media adalah segala sesuatu yang dapat digunakan untuk merangsang pikiran, perasaan, dan kemauan siswa sehingga bisa mendorong terjadinya proses belajar pada siswa.

Sedangkan menurut Gagne (Arief S. Sadiman, 2007: 6), media adalah berbagai jenis komponen dalam lingkungan siswa yang dapat merangsangnya untuk belajar.

Menurut Sudjana (2007: 68), pengertian media gambar adalah media visual dalam bentuk grafis. Media grafis didefinisikan sebagai media yang mengkombinasikan fakta dan gagasan secara jelas dan kuat melalui suatu kombinasi pengungkapan katakata dan gambar-gambar. Sedangkan Azhar Arsyad (1995: 83), mengatakan bahwa media gambar adalah berbagai peristiwa atau kejadian, objek yang dituangkan dalam bentuk gambar-gambar, garis, kata-kata, simbol-simbol, maupun gambaran.

\section{METODE}

Penelitian Tindakan Kelas ini (Classroom Action Research) dengan menerapkan media gambar untuk membaca permulaan. penelitian tindakan kelas ini terdiri dari empat tahapan dasar yaitu perencanaan (planning), pelaksanaan (acting), pengamatan(observing) dan refleksi (reflecting). Analisis penelitian ini adalah analisis deskriptif kuantitafif kualitatif dimana dalam penelitian ini selain penyajian hasil berupa data maupun angka peneliti juga menentukan bagaimana cara pengolahan hasil penelitian yakni dengan membuat analisisnya dengan menerapkan media gambar untuk membaca permulaan. Penelitian ini dilaksanakan pada peserta didik kelas I SD Negeri 03 Kebagusan Tahun Pelajaran 2020/2021 selama dua siklus secara luring menggunakan penjelasan langsung dengan alat bantu LCD dan proyektor dengan satu pertemuan disetiap siklusnya. Siklus I dilaksanakan pada tanggal 16 November 2020. Siklus II dilaksanakan pada tanggal 23 November 2020. Teknik pengumpulan data yang dilakukan dengan observasi dan tes, baik pre test maupun post test. Observasi meliputi observasi keterlaksanaan dengan media gambar, sikap peserta didik dan keterampilan. Untuk hasil belajar menggunakan tes melalui LKPD dan evaluasi.

\section{HASIL DAN PEMBAHASAN}

Pada siklus I pembelajaran dilaksanakan selama satu pertemuan, setiap pertemuan diadakan pre test dan post test. Untuk mengetahui perkembangan peserta didik selama pembelajaran. Siklus I membahas materi tentang keluarga inti, berupa Foto keluarga Udin dan menyebutkan nama dari anggota keluarga Udin. Pembelajaran dengan menggunakan media gambar yaitu berupa foto keluarga secara urut muali dari ayah hingga Udin. merancang proyek, menyusun jadwal, memantau proses proyek, penilaian hasil dan evaluasi pengalaman. Yaitu memasangan nama ayah pada foto ayah, memasangan nama ibu pada foto ibu dan seterusnya. 
Tabel I. Rata-rata Hasil Belajar Membaca Permulaan Siklus I

\begin{tabular}{|c|c|c|c|c|c|c|}
\hline No. & Kelancaran & Lafal/intonasi & Suara & $\begin{array}{l}\text { Nilai } \\
\text { total }\end{array}$ & $\begin{array}{l}\text { Total nilai } \\
\text { skor }\end{array}$ & Kualitas \\
\hline & & Nilai Total & & & 1449 & \\
\hline & & Rata-rata & & & $76,26 \%$ & \\
\hline
\end{tabular}

Berdasarkan tabel di atas maka terjadi peningkatan antara pre test dan post test pada pertemuan 1. Setiap individu peserta didik sudah mengalami peningkatan hasil belajarnya. Peserta didik mengalami peningkatan hasil belajar pada pertemuan 1.Ketuntasan klasikal juga mengalami peningkatan, pada pre test hanya terdapat 5 anak yang sudah tuntas, tetapi pada post test bertambah menjadi 13 anak yang sudah tuntas dengan Kriteria Ketuntasan Minimal (KKM) sebesar 80 \%. Maka untuk pertemuan 1 didapatkan $76,26 \%$.

Berdasarkan refleksi pada siklus I ini, bahwa melalui media gambar dapat meningkatkan kemampuan membaca permulaan. Namun pada siklus I ini masih terdapat kelemahan-kelemahan. Target belum tercapai secara maksimal karena nilai rata-rata kelas pada siklus I hanya 76,26. Melihat kelemahan-kelemahan yang ada pada siklus I dan masih Belum tercapainya target penelitian, maka penelitian dilanjutkan pada penelitian siklus II.

Tabel 2. Rata-rata Hasil Belajar Membaca Permulaan Siklus II

\begin{tabular}{|c|c|c|c|c|c|c|}
\hline No. & Kelancaran & Lafal/intonasi & Suara & $\begin{array}{l}\text { Nilai } \\
\text { total }\end{array}$ & $\begin{array}{l}\text { Total nilai } \\
\text { skor }\end{array}$ & Kualitas \\
\hline & & Nilai Total & & & 1669 & \\
\hline & & Rata-rata & & & $87,8 \%$ & \\
\hline
\end{tabular}

Berdasarkan tabel di atas, maka terjadi peningkatan antara pretest dan post test pada pertemuan I. Setiap individu mengalami peningkatan hasil belajar pada pertemuan 1. Ketuntasan klasikal juga mengalami peningkatan, pada pretes hanya terdapat 13 anak yang sudah tuntas, tetapi pada post test bertambah menjadi 17 anak yang sudah tuntas dengan kriteria ketuntasan minimal $80 \%$, maka untuk siklus II ini didapatkan $87,8 \%$.

Berdasarkan refleksi pada siklus II ini, bahwa melalui media gambar dapat meningkatkan kemampuan membaca permulaan.

Dari dua siklus yang sudah dilaksanakan selama 2 pertemuan dapat dipastikan bahwa media gambar dapat meningkatkan hasil belajar peserta didik pada mupel Bahasa Indonesia Kelas I di SD Negeri 03 Kebagusan. Hal ini sesuai dengan konsep atau teori yang diungkap oleh Sadiman Arief S. (2003:21) media gambar adalah sebuah gambar yang berkaitan dengan materi pelajaran yang berguna untuk menyampaikan pesan dari guru kepada siswa. Peserta didik dapat memahami komponen gambar foto keluarga dan disertai dengan nama. Pada siklus II peserta didik juga dapat memahami gambar foto dari keluarga masing-masing dan bisa menyebutkan nama serta menulisnya. Sehingga anak kelas I SD Negeri 03 Kebagusan dapat memahami pelajaran Bahasa Indonesia yang dipadukan dengan menggunakan media gambar.

Jadi media gambar ini bisa membantu siswa untuk mengungkapkan informasi yang terkandung dalam masalah sehingga hubungan antar komponen dalam masalah tersebut bisa terlihat dengan lebih jelas.

\section{SIMPULAN}


Penerapan membaca permulaan dengan menggunakan media gambar dapat meningkatkan hasl belajar peserta didik kelas I pada mupel Bahasa Indonesia materi keluarga inti. Peningkatan yang terjadi karena adanya kesan pembelajaran yang mendalam dari peserta didik tehadap materi yang diajarkan melalui setiap proyek yang dibuat. Peserta didik akan selalu teringat akan materi yang diajarkan dikarenakan mereka memeragan dengan menggunakan foto keluarga yang mereka bawa sendiri dari rumah. Berdasarkan penelitian yang telah dilaksanakan salah satu media pembelajaran yang harus dikuasai guru adalah media gambar.karena media ini sangat cocok digunakan anak usia 7 tahun yaitu pembelajaran yang menyenangkan dengan membaca permulaan yang disertai dengan gambar-gambar. Guru bisa memantau dengan belajar kelompok dengan bekerja sama dengan orang tua.

\section{DAFTAR PUSTAKA}

Anda Dan. (2014).Tumbuh Kembang Anak Usia 6- 10 tahun, (online), dalam http://nostalgia.tabloidnova.com/articles.asp?id=14344, diakses 24 November 2020.

Aqib, Zainal. (2013). Model-Model, Media, Dan Strategi Pembelajaran Kontekstual (Inovatif). Bandung: CV. Yrama Widya

Armitasari, Ajeng Murti. (2016). Peningkatan Keterampilan Membaca Permulaan Dengan Menggunakan Media KartuKata Bergambar Pada Siswa Kelas IA SD. Jurnal Pendidikan Guru Sekolah Dasar, 37(5).

Asyhar, Rayandra. (2012). Kreatif Mengembangan Media Pembelajaran. Jakarta: Referensi Jakarta

Azhar, Arsyad. (2011). Media Pembelajaran. Cetakan 14. Jakarta: PT RajaGrafindo Persada.

Irdawati, dkk. (2014). Meningkatkan Kemampuan Membaca Permulaan Dengan Menggunakan Media Gambar Kelas I di Min Buol. Junar Kreatif Tadulako. 5(4). ISSN: 2354-614X.

Kunandar. (2011). Langkah Mudah Penelitian Tindakan Kelas Sebagai Pengembang Profesi Guru. Jakarta: PT Raja Grafindo Persada.

Maulana, Auriga. (2012). Membaca Permulaan, (Online), dalam http://akses-ilmublogspot.com/2012/04/membaca-permulaan.html, diakses 24 November 2020.

Puspidalia, Yuentie Sova. (2012). Problematika Pembelajaran Bahasa Indonesia Di MI/SD Dan Alternatif Pemecahannya. Jurnal STAIN Ponorogoo. 10. (2).

Setiadi, Hari. (2016). Pelaksanaan Penilaian Pada Kurikulum 2013. Jurnal Penelitian dan Evaluasi Pendidikan, 20(2), 166-178. 